\title{
THE PROBLEM OF ALCOHOL ABUSE IN THE FAMILY AND LOW ECONOMIC STATUS AS DETERMINANTS OF YOUTH RISK BEHAVIOR
}

\author{
Małgorzata Przybysz-Zaremba \\ State University Stefan Batory in Skierniewice, Poland
}

\begin{abstract}
Objectives: The text presents research on the impact of alcohol problems occurring in the family on the manifestations of youth's risk behavior. Methods: The study was conducted among Polish youth attending junior and senior high schools, as well as their parents. In total, 150 people participated in the study. The study was conducted on the basis of the questionnaire addressed to parents, elaborated by us and the Social Maladjustment Scale developed by Lesław Pytka, addressed to young people. The aim of the study was to find out whether the problem of alcohol abuse observed in at least one parent/guardian and - resulting from that low economic status of the family determine the risk behavior of young people. The study focused to these risky behaviors that are most often manifested by young people, i.e. physical aggression, verbal aggression, alcohol consumption, truancy and excessive sexual behavior. In order to perform statistical analysis, the IBM SPSS statistical program was used. Results: the study confirmed out suppositions that alcohol abuse in the family has a significant impact on the manifestations of adolescent risk behaviors, but this significance has not been fully confirmed for all variables. However, the low economic status of the family only determines selected risk behavior of young people.
\end{abstract}

Keywords: alcohol abuse, alcohol consumption, economic status, family, risky behavior (physical aggression, verbal aggression, truancy and excessive sexual behavior).

\section{Introduction}

A family with an alcohol problem is not a proper environment for the development and education of children and adolescents. The characteristic features spotted there are: chaos, disorganization, emotional instability, high levels of conflict, difficult marital and family relationships, aggression, violence (Polak, Puttler, \& Ilgen, 2012, p 827-836); also poor social and living (economic) conditions can often be found there (Qin, Agerbo, \& Mortenson, 2003, p 765-772; Christoffersen, Poulsen, \& Nielsen, 2003, p. 350). In a family with an alcohol problem, there are also disturbed its basic functions, including the most basic ones, such as: parental, marital, socialization, caring or economic (PrzybyszZaremba, 2018, p 92); as a result, there come out many disorders in the behavior of children and young people. Many studies indicate that a family with an alcohol 
Przybysz-Zaremba, 2020. The Problem of Alcohol Abuse in the Family and Low Economic Status as Determinants of Youth Risk Behavior

problem is becoming a "high risk family" for adolescents (Loukas, Fitzgerald, Zucker, \& Krull, 2003, p 119). Researchers argue that the conflicts prevailing in the family that are the cause of alcohol abuse by one of the parents result in the increase in disorders in the behavior of young people; these may manifest themselves, among others in sadness, depression, anxiety, withdrawal from contact with peers (Preuss, Schuckit, Smith, Barnow, \& Danko, 2002, p 235); in depressive disorders, low self-esteem, low resistance to experienced stress (Haverfield \& Theiss, 2016, p 606-616); such children (youngsters) are also more likely to attempt suicide and exhibit suicidal behavior (Głowiński, Bucholz, Nelson, Fu, Madden, Reich et al., 2001, p 1300-1307; Pisinger, Hawton, \& Tolstrup, 2018, p. 201-208). According to T. Mackrill and M. Hessea (2012, p. 343-348), children of parents who abuse alcohol are at risk to easier reach for alcohol, cigarettes, legal highs and drugs (Przybysz-Zaremba, 2013, p 145-164). These children have also been found to be more likely to exhibit aggressive behavior, truant and earlier take sexualized initiations (Annang, Lianb, Fletcher, \& Jackson, 2014, p 225-237).

The cited studies refer only to two factors related to the family, i.e. the alcohol problem occurring in the family and its low economic status, which to a greater or lesser extent affect the manifestations of risk behavior of young people. There are many different pathological factors in the family (e.g. alcohol and drug problems, aggression, violence, suicidal behavior, etc.), as well as those with no signs of pathology (e.g. poor social and living conditions of the family, economic migration, lack of communication in the family, neglect in raising children and young people, excessive professional activity of parents, lack of parental control, etc.); it is relatively easy to see that each of the above-mentioned situations may also contribute to the manifestations of risky behavior. These factors are often integrated with each other, hence it is difficult to clearly indicate which of them clearly contribute to the indicated risk behavior of young people. In addition, the family is affected by many macro-social factors that may determine the presence of an alcohol problem in it, which in turn may determine its low economic status.

\section{Methodology of the research}

The aim of the study was to find out whether the problem of alcohol abuse by at least one parent and the low economic status of the family determine the risk behavior of young people. The study analyzed the significance of the correlation between at least one parent's alcohol abuse and low family economic status, and adolescent risk behavior such as physical aggression, verbal aggression, alcohol consumption, truancy and excessive sexual behavior. The study used the questionnaire addressed to parents elaborated by us and the Social Maladjustment Scale (SMS) developed by Lesław Pytka (2005) addressed to young people. The 
survey questionnaire consisted of 37 questions about getting to know the family of the respondents and factors inherent in the family, which may determine the risky behavior of young people. The scale of Pytka's social maladjustment, addressed to young people, consisted of six parts (subscales):

1. family maladjustment (FM),

2. peer/peer maladjustment (P/PM),

3. school maladjustment (SM),

4. antisocial behavior (AB),

5. accumulation of adverse biological factors (BF),

6. accumulation of adverse socio-cultural factors (SC). The study used subscale 4 related to antisocial behavior displayed by adolescents (AB). This subscale refers to such behaviors as: lies, verbal and physical aggression, drinking alcohol (alcoholization), truancy, excessive sexual behavior, escaping from home, thefts, self-aggression, disclosed crime. The significance of the correlation was examined between alcohol abuse by at least one parent, low economic status of the family and the following variables: verbal and physical aggression, drinking alcohol, truancy, and excessive sexual behavior. The above-mentioned variables obtained the highest percentage rate in the study. For statistical analysis, the IBM SPSS statistical program was used. The empirical material presented in this paper is only a small part of the research conducted as part of a scientific seminar-based research, supervised by me.

The whole research counted 150 participants: 75 of them were junior and senior high school students in Poland and exactly the same number (75) covered their parents. The whole survey was conducted in the years 2017-2018.

\section{Research data analysis}

In the opinion of the researched parents, the most-risky behaviors of the youngsters were: drinking alcohol (75\%), truancy (56.7\%), verbal aggression (5.4\%), physical aggression (7.9\%), and excessive sexual behavior (18, 3\%).

Risky behavior of young people is influenced by a number of different factors embedded in their living and functioning environments. Among others, one should indicate school environment here, where such factors as: conflicts with teachers, and/or other peers, learning problems, lack of regular attendance at classes, etc. were found (Przybysz-Zaremba, 2018, p 5-26). However, the most important environment in which young people live is the family and a whole range of various factors (that are often integrated with each other) can be determined here as well. Researchers often point to pathological factors, such as the problem of alcohol abuse in the family, as well as factors that do not have signs of 
Przybysz-Zaremba, 2020. The Problem of Alcohol Abuse in the Family and Low Economic Status as Determinants of Youth Risk Behavior

pathology, such as the low economic status of the family. Obviously, these factors do not always determine the risky behavior of young people.

\section{Alcohol abuse by at least one parent / guardian}

Statistical analysis has shown that alcohol abuse by at least one parent has a significant impact on the risk behavior of young people, but not on all types. Studies have revealed that the correlation between alcohol abuse by at least one parent and alcohol consumption by adolescents was .023 - what makes it a low positive correlation. An increase in one variable is accompanied by an increase in the other. This means that the more often parents abuse alcohol, the more often their children (pupils) reach for alcohol. We can speak of a clear, but small relationship. While analyzing the significance of the correlation between alcohol abuse by at least one parent and verbal aggression of youth, the Pearson's correlation between these variables found there was .396. This is again a low, but clear correlation. It can be concluded that the abuse of alcohol by parents slightly increases the likelihood of verbal aggression by young people. At the same time, the correlation between the variable of alcohol abuse by at least one parent and physical aggression of adolescents was established at -.073, what indicates a moderate negative correlation, although the relationship is significant. This means that the increase in one variable (i.e. alcohol abuse) is accompanied by a decrease in the value of the other variable (i.e. physical aggression). This is a result that was not expected in research by us.

Considering the correlation between alcohol abuse by at least one parent and the variable truancy of adolescents, a moderate positive correlation of .061 was noted. This relationship is significant. This also means that alcohol abuse by at least one parent increases the likelihood of truancy by young people.

The variable excessive sexual behavior displayed by young people was also subject to statistical analysis. Pearson's correlation between alcohol abuse by at least one parent/ guardian and the variable indicated above was .136, which shows its weak positive value, but which also reveals no linear relationship between these variables. The relationship is irrelevant here.

\section{Low economic status of the family}

The low economic status of the family may determine the risky behavior of young people. Statistical analysis showed that the low economic status of the family correlates with alcohol consumption by young people at the level of .118. This means that the correlation is weak positive, and therefore almost insignificant. Thus, the low economic status of the family slightly increases the likelihood of alcohol being drunk and consumed by the surveyed youth. The 
correlation between the low economic status of the family and physical aggression of young people was. 265, what indicates a positive low correlation. On this basis, it can be assumed that the low economic status of the family slightly increases the likelihood of manifestations of physical aggression in adolescents (similarly to the variable 'drinking alcohol by adolescents'). The variable verbal aggression manifested by youth was also subject to statistical analysis. The correlation between the low economic status of the family and the indicated variable was at the level of -050 , which indicates a significant relationship. This means that the low economic status of the family reduces the likelihood of verbal aggression in the surveyed youth. In this hypothesis no such correlation was expected. Positively, but at a low level, the low economic status of the family correlates with the truancy manifested by young people. The correlation was at .246; this relationship is clear, but small. Thus, the lower the economic status of a family, the higher the frequency of truant youth attendance. The last of the analyzed variables is the low economic status of the family and excessive sexual behavior displayed by young people. Studies have shown that the correlation between these variables was at the level of .161, being recognized as almost insignificant. Based on this, it can be assumed that the lower the economic status of the family, the less often the researched youth either exhibit different forms of excessive sexual behavior or does not exhibit them at all (the assumed hypothesis has not been confirmed).

To sum up, the low economic status of the family correlates most strongly with physical aggression and the truancy displayed by young people. However, in the case of drinking alcohol by young people, expressing verbal aggression and undertaking sexual behavior, the examined variable does not matter much.

Table 1 Results of the statistical analysis (own elaboration)

\begin{tabular}{|l|c|c|}
\hline \multirow{2}{*}{ Risky behavior of youth } & \multicolumn{2}{|c|}{ Pearson correlation $r$} \\
\cline { 2 - 3 } & $\begin{array}{c}\text { Alcohol abuse by at least one } \\
\text { person in a family }\end{array}$ & $\begin{array}{c}\text { Low economic status of the } \\
\text { family }\end{array}$ \\
\hline Alcohol abuse by the youth & .023 & .118 \\
\hline Physical aggression & -.073 & .265 \\
\hline Verbal aggression & .396 & -.050 \\
\hline Truancy & .061 & .246 \\
\hline Excessive sexual behavior & .136 & -.059 \\
\hline
\end{tabular}

Source: own study based on research.

\section{Conclusions and discussion of research}

Pathological behavior in the family, which undoubtedly includes the abuse of alcohol by parents, determines many problems and dysfunctions of the family, children raised in such families being primarily included. The conducted research 
Przybysz-Zaremba, 2020. The Problem of Alcohol Abuse in the Family and Low Economic Status as Determinants of Youth Risk Behavior

indicates that the more often parents abuse alcohol, the more often adolescents (pupils) reach for alcohol. This observation was also confirmed by the researches done by Przybysz-Zaremba, (2014), or Cannavò, Santi, Grecò, Laganà, (2009) among others. This situation looks similar in the case of aggressive behavior of young people; the family environment in which the alcohol problem occurs has a significant impact on the manifestations of aggressive behavior of young people. Although in this study the correlation between these variables was low but clear (in the case of verbal aggression) and negative, but moderate (in the case of physical aggression), many studies (Clark, Lutke et al., 2004; Przybysz-Zaremba, 2017; Siudem, 2013), indicate that the pathological family environment is destructive to the development and upbringing of both children and youngsters. The problem of alcohol abuse in the family (recognized in at least one parent) increases the likelihood of truancy by young people, which has been confirmed in many previous studies. However, this cannot be said for the manifestations of youth's excessive sexual behavior. Studies have shown that Pearson's correlation $r$ between alcohol abuse by at least one parent/guardian and excessive sexual behavior of the adolescents remains weak but positive (what has been assessed as insignificant). This may be due to a lack of interest among young people in this type of risky behavior.

The low economic status of the family may determine the risky behavior of young people (Przybysz-Zaremba, 2017, pp. 137-148; Qin, Agerbo, \& Mortenson, 2003, pp. 765-772), but in the case of the research discussed here no significant correlation between the indicated variables was discovered. Studies have shown that the low economic status of the family slightly increases the likelihood of young people reaching for alcohol and/or getting involved in various forms of physical aggression. In this case, an important role may be played by such factors as, for example, the individual, his/her personality, attachment to the family, proper communication with the parent, obtained support and/or help from the family.

On the other hand, the low economic status of the family has a significant impact on truancy of young people, while it reduces the likelihood of verbal aggression and their complete lack of significance for excessive sexual behavior. Truancy of young people may be associated with a lack of control and supervision by parents who, due to the poor social and living (economic) conditions of the family, are forced to undertake many professional activities and sometimes migrate in order to look for a better-paid job. Current research confirms that excessive professional activity or professional migration leads to many problems and disorders in the behavior of children and/or adolescents coming from such families. They manifest themselves in the form of excessive dropping out of classes without justification (truancy), deviant disorders, manifestations of various types of risky behaviors, or depression disorders (Przybysz-Zaremba, 
2017, pp. 260-275; Abas et al., 2013, pp. 226-234; Kozak, 2010). The lack of significance related to verbal aggression and excessive sexual behavior by young people may result from the personality of the individuals, their character, approach to life and skills related to problem solving, and perhaps with a stronger impact of the factors customarily recognized as protecting family, school or the individual. Research indicates that such factors as: warmth, support, emotional closeness of parents with children, tenderness and sensitivity to problems and needs of children and adolescents are the main factors protecting young people from manifesting risky behavior (Hou, Wu, \& Liu, 2013, p. 1387- 1398). These components build the further life of young people - deciding who they will become in the future.

\section{References}

Abas, M., Tangchonlatip, K., Punpuing, S., Jirapramukpitak, T., Darawuttimaprakorn, N. et al. (2013). Migration of children and impact on depression in older parents in rural Thailand, southeast Asia. JAMA Psychiatry, 2(70), 226-234.

Annanga, L., Lianb, B., Fletcherc, F.E., \& Jacksona, D. (2014). Parental attitudes about teenage pregnancy: impact on sexual risk behaviour of African-American youth. Sex Education, 14(2), 225-237. DOI: https://doi.org/10.1080/14681811.2013.867480

Cannavò, G., Santi, D.M., Grecò, C., \& Laganà, P. (2009). Adolescents and alcohol: a survey in the city of Messina (Italy). Igiene E Sanità Pubblica [Ig Sanita Pubbl], 1-2, 65(1), 53-68

Christoffersen, M.N., Poulsen, H.D., \& Nielsen, A. (2003). Attempted suicide among young people: risk factors in a prospective register based study of Danish children born in 1966. Acta Psychiatrica Scandinavica, 11, 108(5), 350. DOI: 10.1034/j.16000447.2003.00165.x

Clark, E., Lutke, J., Minnes, P., \& Ouellette Kuntz, H. (2004). Secondary disabilities among adults with fetal alcohol spectrum disorder in British Columbia. Journal of FAS International, 2(e13), 1-12.

Głowiński, A.L., Bucholz, K.K., Nelson, E.C., Fu, Q., Madden, P.A.F., Reich, W., et al. (2001). Suicide attempts in an adolescent female twin sample. JAmAcadChildAdolesc Psychiatry, 40, 1300-1307.

Haverfield, M.C., \& Theiss, J.A. (2016). Parent's alcoholism severity and family topic avoidance about alcohol as predictors of perceived stigma among adult children of alcoholics: Implications for emotional and psychological resilience. Health Communication, 5(31), 606-616. DOI:10.1080 / 10410236.2014.981665

Hou, Ch., Wu, L., \& Liu, Z. (2013). Parental emotional Warmth and Career Decision-Making Difficulties: A Model of Intellectual-Cultural orientation and Conscientiousness. Social Behavior and Personality, 41(8), 1387-1398. DOI: doi.org/10.2224/sbp.2013.41.8.1387

Kozak, S. (2010). Patologia eurosieroctwa w Polsce. Skutki migracji zarobkowej dla dzieci i ich rodzin. [Eng: Euro-orphan pathology in Poland. Effects of labor migration for children and their families.] Warszawa: Difin.

Loukas, A., Fitzgerald, H.E., Zucker, R.A., \& Krull, J.L. (2003). Developmental Trajectories of Disruptive Behavior Problems Among Sons of Alcoholics: Effects of Parent 
Przybysz-Zaremba, 2020. The Problem of Alcohol Abuse in the Family and Low Economic Status as Determinants of Youth Risk Behavior

Psychopathology, Family Conflict, and Child Undercontrol. Journal of Abnormal Psychology, 112(1), 119-131. DOI: doi.org/10.1037/0021-843X.112.1.119

Mackrilla, T., \& Hessea, M. (2012). Suicide behavior in parents with alcohol abuse problems and suicide behavior in their Offspring - Adult offspring and counselor perspectives. Nordic Journal of Psychiatry, 10(66), 343-348.

Pisinger, V.S.C., Hawton, K., \& Tolstrup, J.S. (2018). Self-injury and suicide behavior among young people with perceived parental alcohol problems in Denmark: a school-based survey. European Child \& Adolescent Psychiatry, 2(27), 201-208.

Polak, K.A., Puttler, L.I., \& Ilgen, M.A. (2012). The Relationship between Structural Aspects of Self-Concept and Psychosocial Adjustment in Adolescents from Alcoholic Families. In: Substance Use \& Misuse, 5(47), 827-836.

Preuss, U.W., Schuckit, M.A., Smith, T.L., Barnow, S., \& Danko, G.P. (2002). Mood and anxiety symptoms among 140 children from alcoholic and control families. Drug \& Alcohol Dependence, 8(67), 235-242. DOI: 10.1016 / S0376-8716 (02) 00076-5.

Przybysz-Zaremba, M. (2014). Ryzykowne zachowania młodzieży jako implikacja dekompozycyjnych oddziaływań środowiska rodzinnego - wybrane konteksty i eksploracje. [Eng: Risky behavior of young people as an implication of decomposition impacts of the family environment - selected contexts and explorations.] Studia nad Rodzina [Eng: Studies on Family Problems], 2(34), 229-239.

Przybysz-Zaremba, M. (2017). Uwarunkowania rodzinne zachowań ryzykownych dzieci i młodzieży - analiza wybranych czynników. [Eng: Family conditions of risky behavior of children and youth - analysis of selected factors.] Forum Pedagogiczne [Eng.: Pedagogical Forum], 1, 141-152. DOI: 10.21697/fp.2017.1.10.

Przybysz-Zaremba, M. (2018). Rodzina z problemem alkoholowym - studium przypadku. W kierunku pomocy i wsparcia. [Eng: A family with an alcohol problem - a case study. Towards help and support.]. Studia nad Rodzina [Eng: Studies on Family Problems], 47, 91-106.

Przybysz-Zaremba, M. (2013). Alkohol i nieletni - rekapitulacja problemu. [Eng.: Alcohol and minors - recapitulation of the problem.] In L. Hurło, M. Przybysz-Zaremba, W. Ziarek (Eds.), Rodzina. Uzależnienia. Bezpieczeństwo. Studium Socjopedagogiczne, [Eng: Family. Addiction. Security. A Socio-Pedagogical Study.] (pp. 145-164). Olsztyn: Oficyna Wydawnicza Prospekt.

Przybysz-Zaremba, M. (2015). Zachowania ryzykowne dzieci i młodzieży - eksplikacje, kontemplacje, egzemplifikacje, eksploracje. [Eng: Risky behavior of children and adolescents - explications, contemplations, exemplifications, explorations.] In M. Przybysz-Zaremba (Ed.), Zachowania ryzykowne dzieci i młodzieży. Heterogeniczny wymiar oddziatywań profilaktycznych. Wybrane aspekty. [Eng: Risky behavior of children and adolescents. Heterogeneous dimension of preventive actions. Selected aspects.] (pp. 5-26). Olsztyn: Wydawnictwo Prospekt PR.

Pytka, L. (2005). Pedagogika resocjalizacyjna. [Eng: Pedagogy of Rehabilitation.], Warszawa: Wydawnictwo Akademii Pedagogiki Specjalnej.

Siudem, A. (2013). Zachowania ryzykowne młodzieży gimnazjalnej. [Eng: Risky behavior of junior high school students.] Psychologia rozwojowa [Eng: Developmental Psychology], 13(1), 69-85. DOI: 10.4467/20843879PR.13.005.1017

Qin, P., Agerbo, E., \& Mortenson, P.B. (2003). Suicide risk in relation to socioeconomic, demographic, psychiatric, and familial risk factors: A national register-based study of all suicides in Denmark, 1981-1997. American Journal of Psychiatry, 160, 765-772. DOI: 10.1176/appi.ajp.160.4.765 